\title{
Probleme privind malpraxisul în activitatea medicală
}

Stimați membri ai Societății Române de Ultrasonografie în Medicină și Biologie,

În luna februarie a. c. Societatea Română de Ultrasonografie în Medicină și Biologie a avut plăcerea de a onora o invitație primită din partea Academiei Române și de a fi reprezentată alături de alți președinți ai societăților profesionale medicale și reprezentanți ai comunităților academice medicale la o întrunire care a vizat constituirea Asociației pentru Apărarea Medicilor AAM, precum și realizarea unui Registru național al specialităților medicale.

Această Asociație - AAM are ca și obiectiv profesional realizarea unor ample demersuri privind propunerea unei noi legislații referitoare la exercitarea profesiunii medi- cale, definirea și combaterea malpraxis-ului medical.

Alături de alte 45 de societăți savante medicale, Societatea Română de Ultrasonografie în Medicină și Biologie a aderat, în calitate de parte semnatară, la Memorandumul de colaborare pentru problematica sancționării penale a greșelii medicale.

Prima acțiune comună necesară pentru realizarea obiectivelor Memorandumului o constituie informarea medicilor în legătură cu vulnerabilitățile actuale ale practicii medicale și soluțiile concrete, eficiente și complete de apărare.

O serie de documente realizate de către d-nul Şef lucr. dr. Andrei Nanu, de la UMF Carol Davila București, privind numeroase implicații de malpraxis cu care ne putem confrunta pe parcursul actualei pandemii sunt postate pe site-ul SRUMB (www. srumb.ro) unde vă rugăm să le consultați, alături de alte informații actualizate.

De asemenea avem rugămintea de a ne transmite prin e-mail (srumb.secretariat@ gmail.com) aspecte de potențial malpraxis sau probleme pe care le-ați întâmpinat și/ sau considerați că ar trebui soluționate.

Cu deosebită considerație,

Prof. dr. Viorela Enăchescu

Președinte Executiv SRUMB (2018-2020)

Prof. dr. Zeno Spârchez

Secretar General SRUMB 